\title{
Upaya Sekolah dalam Meningkatkan Kompetensi Guru PAI yang Belum Tersetifikasi Di MA Al-Hikmah Langkapan Srengat Blitar
}

\author{
Anindhita Chumaida ${ }^{1}$ \\ ${ }^{1}$ Institut Agama Islam Negeri Tulungagung \\ Email: ${ }^{1}$ dac358@gmail.com
}

\section{Tersedia Online di \\ http://www.jurnal.unublitar.ac.id/ index.php/briliant}

\begin{tabular}{l}
\hline Sejarah Artikel \\
\hline Diterima pada 2 November 2017 \\
Disetuji pada 2 November 2017 \\
Dipublikasikan pada 13 \\
November 2017 Hal. $470-481$ \\
\hline
\end{tabular}

\section{Kata Kunci:}

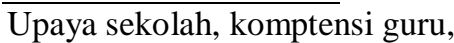
pai ,

\section{DOI:}

http://dx.doi.org/10.28926/briliant .$v 2 \mathrm{i} 4.108$

\begin{abstract}
Abstrak: Tujuan dari penelitian ini adalah Untuk mengetahui upaya sekolah dalam meningkatkan kompetensi pedagogig, kepribadian, sosial, dan professional guru PAI yang belum tersertifikasi di MA Al-Hikmah Langkapan Srengat Blitar. Pendekatan dalam penelitian ini adalah metode kualitatif dengan jenis penelitian studi kasus. Hasil penelitian menunjukkan hasil bahwa Upaya sekolah adalah workshop, seminar, diklat, MGMP, supervisi konvensional, evaluasi kerja, IHT (In House Training). Pembinaan melalui kegiatan rapat dan supervisi, pembinaan dengan memberikan keteladanan. pertemuan wali murid sebagai upaya meningkatkan kemampuan berkomunikasi guru dengan orang tua siswa, rapat guru sebagai upaya meningkatkan kemampuan berkomunikasi dengan teman sejawat.
\end{abstract}

Perkembangan dan kemajuan suatu bangsa salah satunya ditentukan dengan eksistensi pendidikan. Jika pendidikan memiliki kualitas tinggi, maka akan memberikan output sumber daya manusia yang mumpuni, tidak hanya sebagai pelaku pembangunan negara, tetapi juga berkarakter sebagai khalifah di muka bumi. Pendidikan pada hakikatnya adalah suatu proses pembelajaran yang dilakukan tanpa henti. Hal itu sesuai dengan yang dikatakan Salim \& Kurniawan (2012:28-29) bahwa Pendidikan adalah seluruh aktivitas atau upaya secara sadar yang dilakukan oleh pendidik kepada peserta didik terhadap semua aspek perkembangan kepribadian, baik jasmani maupun ruhani, secara formal, informal, maupun non-formal yang berjalan terus menerus untuk mencapai kebahagiaan dan nilai yang tinggi, baik nilai insaniyah maupun ilahiyah.

Pendidikan berlandaskan Islam adalah proses pendidikan yang bersumber pada kitab suci Al-Qur'an dan Sunnah serta pendapat para sahabat dan ulama Muslim. Sesuai dengan pendapat Salim \& Kurniawan (2012:33), bahwa Pendidikan Islam adalah segala upaya atau proses pendidikan yang dilakukan untuk membimbing tingkah laku manusia, baik individu, maupun sosial untuk mengarahkan potensi, baik potensi dasar (fitrah), maupun ajar yang sesuai dengan fitrahnya melalui proses intelektual dan spiritual berlandaskan nilai Islam untuk mencapai kebahagiaan hidup di dunia dan akhirat.

Pendidikan, baik formal, informal, maupun non-formal, memiliki agenda dan tugas untuk merumuskan, mengarahkan, dan membentuk pribadi-pribadi manusia sesuai dengan cita-cita dan tujuan yang dikehendaki. Terlebih dalam pendidikan yang berlandaskan Islam, tugas yang diampu tidak bisa dikatakan 
mudah. Pendidikan Islam memiliki tugas yang bertujuan mengarahkan potensi manusia sesuai fitrahnya melalui proses intelektual dan spiritual berdasarkan nilainilai Islam untuk mencapai kebahagiaan hidup di dunia dan akhirat.

Tercapainya tujuan pendidikan, tidak terlepas dari peran seorang guru. Sebab, guru merupakan salah satu pilar utama keberhasilan dunia pendidikan yang akan melahirkan output yang berkualitas, bahkan guru pula yang dapat menentukan maju dan mundurnya sebuah Negara. Dengan demikian, perhatian terhadap tenaga pendidik, terutama seorang guru harus lebih ditingkatkan, terutama dalam hal kompetensi dan kualitasnya.

Guru yang memiliki tingkatan kompetensi tinggi akan mampu melaksanakan tugasnya sebagi guru dengan baik dan penuh tanggung jawab. Hal ini, dipertegas oleh Basri (2012:64) yang mengutip teks UU No. 14 tahun 2005, tentang guru dan dosen, bahwa Seorang guru atau dosen harus memiliki empat kompetensi, yaitu kompetensi pedagogig, kompetensi profesional, kompetensi kepribadian, dan kompetensi sosial.

Kompetensi professional merupakan kemampuan penguasaan materi pelajaran secara luas dan mendalam. Hal ini dipertegas oleh Kunandar (2009:45) yang mengutip teks UU Nomor 14 Tahun 2005 tentang guru dan dosen, menyatakan bahwa Profesional adalah pekerjaan atau kegiatan yang dilakukan oleh seseorang dan menjadi sumber penghasilan kehidupan yang memerlukan keahlian, kemahiran, atau kecakapan yang memenuhi standar mutu atau norma tertentu serta memerlukan pendidikan profesi.

Kompetensi pedagogig adalah kemampuan mengelola pembelajaran peserta didik. Hal ini diperjelas oleh Mulyasa (2008:117) yang mengutip teks Standar Nasional Pendidikan, penjelasan pasal 28 ayat (3) butir a dikemukakan bahwa kompetensi pedagogik adalah kemampuan mengelola pembelajaran peserta didik yang meliputi pemahaman terhadap peserta didik, perancangan dan pelaksanaan pembelajaran, evaluasi hasil belajar, dan pengembangan peserta didik untuk mengaktualisasikan berbagai kompetensi yang dimilikinya. Dalam Standar Nasional Pendidikan, penjelasan Pasal 28 ayat (3) butir b, dikemukakan bahwa yang dimaksud dengan kompetensi kepribadian adalah kemampuan kepribadian yang mantap, stabil, dewasa, arif, dan berwibawa, menjadi teladan bagi peserta didik, dan berakhlak mulia (Mulyasa, 2008:173). Selain itu, dijelaskan pula dalam Standar Nasional Pendidikan, penjelasan Pasal 28 ayat (3) butir di dikemukakan bahwa yang dimaksud dengan kompetensi sosial adalah kemampuan guru sebagai bagian dari masyarakat untuk berkomunikasi dan bergaul secara efektif dengan peserta didik, sesama pendidik, tenaga kependidikan, orang tua/ wali peserta didik, dan masyarakat sekitar (Mulyasa, 2008:173).

Berdasarkan penjelasan di atas, keberadaan guru yang memiliki kompetensi profesional, pedagogig, kepribadian, dan sosial yang tinggi sangat dibutuhkan dalam dunia pendidikan. Karena, keberadaan guru dalam dunia pendidikan sangat krusial, sebab kewajibannya tidak hanya menginternalisasikan pengetahuan (knowledge) tetapi juga dituntut mentransformasikan nilai-nilai (value) pada anak didik. Bentuk nilai yang ditransformasikan dan disosialisasikan meliputi : nilai etis, nilai pragmatis, nilai efek sensorik dan nilai religious (Ramayulis, 2004:83).

Namun Pada Faktanya, dibeberapa sekolah masih ada sebagian guru yang belum menguasai 4 kompetensi sebagaimana mestinya. Hal ini didukung 
oleh Atik Dwi Puji Hastuti, dalam penelitiannya yang berjudul Profesionalisme Guru dalam Pembelajaran Al-Qur'an Hadits di MAN Sabdodadi Bantul, mengatakan bahwa Dari ketiga guru Al-Quran Hadits semua telah mempunyai kompetensi pedagogig, hanya saja dalam pembelajaran strategi yang digunakan kurang variatif. Sedangkan untuk kompetensi profesional; kemampuan guru dalam menguasai materi dan ilmu yang terkait. Pada kompetensi ini ada kekurangan, karena guru Al-Quran Hadits kurang menguasai struktur dan metode keilmuan (Hastuti, 2008).

Dari penjelasan di atas, dapat diketahui bahwa kompetensi yang dimiliki beberapa guru masih kurang, padahal kompetensi itu penting, dimana salah satunya ditandai dengan sertifikasi. Namun, pada faktanya masih banyak guru yang belum tersertifikasi, seperti di MA Al-Hikmah Langkapan Srengat. Peningkatan kompetensi itu sendiri, menjadi tanggung jawab lembaga dan pemerintah. Seperti halnya di MA Al-Hikmah, upaya yang dilakukan sekolah dalam meningkatkan kompetensi guru PAI di antaranya adalah dengan mengirimkan guru untuk mengikuti kegiatan seminar, workshop, dan diklat. Hal ini berdasarkan studi pendahuluan yang telah penulis lakukan di MA Al-Hikmah Langkapan Srengat Blitar.

Kemudian, hal inilah yang membuat peneliti tertarik untuk melaksanakan penelitian terkait bagaimanakah upaya yang dilakukan oleh sekolah dalam meningkatkan kopetensi guru. Karena tentunya sekolah mempunyai strategi ataupun upaya-upaya demi meningkatkan kompetensi yang dimiliki guru. Oleh karena itu tujuan penelitian ini adalah Untuk mengetahui upaya sekolah dalam meningkatkan kompetensi guru PAI yang belum tersertifikasi di MA Al-Hikmah Langkapan Srengat.

\section{METODE}

Jenis penelitian yang digunakan peneliti dalam penelitian ini adalah studi kasus. Penelitian studi kasus adalah penelitian yang bertujuan untuk mempelajari secara intensif mengenai unit sosial tertentu, yang meliputi individu, kelompok, lembaga, dan masyarakat (Zuariah, 2009:48). Menurut Suharsimi Arikunto penelitian studi kasus adalah suatu penelitan yang dilakukan secara intensif, terinci dan mendalam terhadap suatu organisasi, lembaga atau gejala tertentu (Arikunto, 2002:120). Sehingga penelitian ini berusaha mengamati apa yang dilihat dan dialami peneliti dilapangan secara mendalam.

Peneliti melakukan penelitian di Madrasah Aliyah Al-Hikmah Langkapan Srengat. Madrasah tersebut beralamat di Jalan Masjid nomor 07 Maron Kecamatan Srengat Kabupaten Blitar. Hal yang menjadi latar belakang pemilihan lokasi ini adalah MA Al-Hikmah merupakan Madrasah Aliyah swasta yang berada di bawah naungan yayasan Al Hikmah, di mana dalam MA AlHikmah masih banyak terdapat tenaga pengajar atau guru PAI yang masih belum tersertifikasi. Sehingga data yang dibutuhkan dalam penelitian ini tersedia di MA Al-Hikmah Langkapan.

Pengumpulan data dan informasi dalam penelitian ini dilakukan dengan beberapa cara dan teknik yang berasal dari berbagai sumber. Dalam penelitian ini menggunakan teknik pengumpulan data berupa observasi, wawancara dan dokumentasi. Analisis data yang digunakan menggunakan teknik reduksi data, penyajian data, dan penarikan kesimpulan (Miles, Hubberman \& Saldana, 2014). 


\section{HASIL}

Upaya Sekolah dalam Meningkatkan Kompetensi Pedagogig Guru PAI yang Belum Tersertifikasi Di MA Al-Hikmah Langkapan Srengat

Kompetensi pedagogig adalah kemampuan mengelola pembelajaran peserta didik yang meliputi pemahaman terhadap peserta didik, perancangan dan pelaksanaan pembelajaran, evaluasi hasil belajar dan pengembangan peserta didik untuk mengaktualisasikan berbagai potensi yang dimilikinya. Untuk meningkatakan dan mengembangkan kompetensi pedagogig yang dimiliki oleh guru, sekolah menerapkan beberapa upaya yang dilakukan, diantaranya adalah melakukan workshop, seminar, diklat, MGMP, Supervisi Konvensional, evaluasi kinerja, In House Training.

\section{Upaya Sekolah dalam Meningkatkan Kompetensi Kepribadian Guru PAI yang Belum Tersertifikasi Di MA Al-Hikmah Langkapan Srengat}

Kompetensi kepribadian adalah kepribadian pendidik yang mantap,stabil, dewasa, arif daan berwibawa, menjadi teledan bagi peserta didik dan berakhlak mulia. Untuk meningkatakan dan mengembangkan kompetensi kepribadian yang dimiliki oleh guru, sekolah menerapkan beberapa upaya yang dilakukan, diantaranya adalah: Pembinaan Melalui Kegiatan Rapat dan Supervisi, Pembinaan dengan Memberikan Keteladanan.

\section{Upaya Sekolah dalam Meningkatkan Kompetensi Sosial Guru PAI yang} Belum Tersertifikasi Di MA Al-Hikmah Langkapan Srengat

Kompetensi sosial adalah kemampuan pendidik berkomunikasi dan berinteraksi secara secara efektif dengan peserta didik, sesama pendidik,tenaga kependidikan, orang tua atau wali peserta didik dan masyarakat. Untuk meningkatakan dan mengembangkan kompetensi sosial yang dimiliki oleh guru, sekolah menerapkan beberapa upaya yang dilakukan, diantaranya adalah Pertemuan Wali Murid sebagai Upaya Meningkatkan Kemampuan Berkomunikasi Guru dengan Orang Tua Siswa, Rapat Guru sebagai Upaya Meningkatkan Kemampuan Berkomunikasi dengan Teman Sejawat, Pembinaan dari Kepala Sekolah Melalui Kegiatan Supervisi.

\section{Upaya Sekolah dalam Meningkatkan Kompetensi Profesional Guru PAI yang Belum Tersertifikasi Di MA Al-Hikmah Langkapan Srengat}

Kompetensi professional adalah kemampuan pendidik dalam penguasaan materi pembelajaran secara luas dan mendalam yang memungkinkannya membimbing peserta didik memperoleh kompetensi yang diharapkannnya. Untuk meningkatakan dan mengembangkan kompetensi profesional yang dimiliki oleh guru, sekolah menerapkan beberapa upaya yang dilakukan, diantaranya adalah Supervisi, Diklat, MGMP, Workshop.

\section{PEMBAHASAN}

\section{Workshop}

Workshop merupkan salah satu bentuk pelatihan yang ditujukan kepada guru dalam upaya meningkatkan kompetensi guru terutama kompetensi pedagogig. Workshop yang dilakukan dalam dunia pendidikan adalah suatu 
kegiatan yang dilakukan untuk mengembangkan kesanggupan berfikir dan bekerja bersama-sama secara kelompok ataupun bersifat perseorangan untuk membahas dan memecahkan segala permasalahan yang ada baik mengenai masalah-masalah yang bersifat teoritis maupun yang bersifat raktis dengan tujuan untuk dapat meningkatkan kualitas kompetensi pedagogik guru sehingga dapat menyelesaikannya sesuai tugas masing-masing (Purwanto, 1984:7).

Workshop dilakukan untuk menghasilkan guru yang memiliki kemampuan berfikir yang baik dalam kgiatan pembelajaran. Dalam kegiatan workshop tersebut guru akan mendapatkan pelatihan yang berisi penyampaian materi yang sesuai dengan tema workshop tersebut. Sebagaimana disampaikan Sudarman Danim bahwa workshop dapat dilakukan misalnya dalam kegiatan menyusun KTSP, analisis kurikulum, pengembangan silabus, penulisan Rpp, dan sebagainya (Danim, 2013:33).

\section{Seminar}

Seminar merupakan suatu pertemuan persidangan untuk membahas suatu masalah di bawah pimpinan ketua sidang (guru besar atau seorang ahli). Pertemuan atau persidangan dalam seminar biasanya menampilkan suatu atau beberapa pembicara dengan makalah atau kertas kerja masing-masing. Seminar biasanya diadakan untuk membahas suatu masalah secara ilmiah. Yang berpartisipasipun orang yang ahli dalam bidangnya. Seminar tentang pemasaran suatu produk, peserta berperan untuk menyampaikan pertanyaan, usulan, dan pembahasan sehingga menghasilkan pemahaman tentang suatu masalah (Purwanto, 1984:108).

Mengikutsertakan guru dalam seminar dan publikasi ilmiah juga dapat menjadi model pembinaan berkelanjutan bagi peningkatan kompetensi pedagogik guru. Kegiatan ini memberikan peluang kepada guru untuk berinteraksi secara ilmiah dengan kolega seprofesinya berkaitan dengan hal-hal terkini. Selain itu, Seminar ini juga berfungsi sebagai media komunikasi untuk saling memberikan andil pengetahuan dan bertukar pengalaman selain itu juga tempat ilmuan untuk mengidentifikasikan masalah, mengembangkan rencana dan metologi penelitian, dan tempat ilmuan memikirkan cara bagaimana menerapkan hasil penelitiannya.

\section{Diklat}

Diklat merupakan kegiatan yang dilakukan sekolah untuk meningkatkan kompetensi guru. Diklat itu sendiri pada hakikatnya merupakan salah satu bentuk kegiatan program pengembangan sumberdaya manusia (personil development). Hal ini dipertegas oleh pendapat Castetter yang dikutip oleh Wahyosumidjo (2007:380), mengatakan bahwa Diklat merupakan proses perbaikan staf melalui berbagai macam pendekatan yang menekankan realisasi diri (kesadaran), pertumbuhan pribadi dan pengembangan diri. Pengembangan mencakup kegiatankegiatan yang bertujuan untuk perbaikan dan pertumbuhan kemampuan (abilities), sikap (attitudes), kecakapan (skills) dan pengetahuan dari anggota organisasi.

Berdasarkan hasil penelitian di MA Al-Hikmah Langkapan, program diklat hanya bisa dilakukan dengan cara mengikutsertakan guru dalam diklat apabila sekolah mendapatkan undangan. Undangan Diklat tersebut berasal dari pihak-pihak yang menyelenggarakan, dengan kata lain sekolah tidak memprogramkan dan menyelenggarakan Diklat tetapi sekolah hanya mengikuti/ 
mengikutsertakan Diklat yang diadakan oleh lembaga-lembaga maupun perguruan tinggi terkait.

\section{MGMP}

Musyawarah Guru Mata Pelajaran (MGMP) merupakan salah satu kegiatan yang dilakukan oleh sekolah yang ditujukan kepada guru-guru mata pelajaran. Kegiatan MGMP adalah kegiatan yang diselenggarakan oleh Dinas Pendidikan, sehingga setiap sekolah wajib mengikutsertakan guru sesuai dengan mata pelajaran yang diampunya. Dalam forum MGMP terdapat beberapa kegiatan yang dilakukan guna mendukung peningkatan kualitas bagi guru seperti: pemberian materi yang berhubungan dengan pengembangan silabus. Sebagaimana dikemukakan oleh Mulyawatu (2005) bahwa MGMP adalah salah satu bentuk bentuk penataran yang diselenggarakan oleh guru dan pesertanya juga guru-guru tersebut, yang memiliki manfaat sebagai berikut: a) MGMP merupakan wadah yang efektif untuk menyelesaikan permasalahan yang dihadapi guru di kelas, b) satu MGMP terdiri dari sejumlah guru yang memiliki gaya mengajar yang berbeda dan memiliki siswa dengan karakteristik berbeda pula, sehingga mereka dapat berbagi pengalaman dan mencari solusi permasalahan yang dihadapi di kelas, c) memfasilitasi kebutuhan yang diperlukan guru, karena program MGMP ini dirancang sesuai dengan kebutuhan guru mata pelajaran.

\section{Supervisi Konvensional}

Pelaksanaan Supervisi konvensional oleh kepala sekolah juga termasul dalam upaya meningkatkan kompetensi pedagogig yang telah dimiliki guru. Tujuan dari diselenggarakannya supervisi itu sendiri adalah untuk memberikan bantuan teknis dan bimbingan kepada guru (dan staf sekolah lain) agar personil tersebut dapat meningkatkan kualitas kinerjanya, terutama dalam melaksanakan tugas, yaitu melaksanakan proses pembelajaran.

Dalam pelasanaan supervisi konvensional ini, kepala sekolah sering mengadakan pemeriksaan kepada guru terkait kelengkapan perangkat pembelajaran yang telah disusun. Disamping itu kepala sekolah juga melaksanakan observasi atau kunjungan ke kelas tanpa sepengetahuan dari guru. Kunjungan ke kelas dilakukan kepala sekolah sebagai salah satu teknik untuk mengamati kegiatan pembelajaran secara langsung. Kunjungan ke kelas merupakan teknik yang sangat bermanfaat untuk mendapatkan informasi secara langsung tentang berbagai hal yang berkaitan dengan profesionalisme guru dalam melaksanakan tugas pokoknya yaitu mengajar (Musbakin, 2013:32).

Berdasarkan penjelasan tersebut dapat kita simpulkan, bahwa pelaksanaan supervisi dilakukan dengan mencari kesalahan dari guru, dan pelasanaan inspeksi seringkali tanpa sepengetahuan dari guru. Hal ini sejalan dengan yang diungkapkan Mufidah dalam bukunya Supervisi pendidikan bahwa Dalam model supervisi yang konvensional atau tradisonal, pemimpin cenderung untuk mencari-cari kesalahan. Prilaku supervisi adalah mengadakan inspeksi untuk mencari kesalahan dan menemukan kesalahan. Kadang-kadang bersifat memata-matai (Kunandar, 2007:367).

Dari uraian tersebut menunjukkan bahwa, praktek mencari kesalahan dan menekan bawahan ini masih tampak sampai saat ini. Para pengawas datang ke sekolah dan menanyakan mana satuan pelajaran, kemudian memberi peringatan 
ini salah harusnya begini,. Praktek-praktek supervisi seperti ini adalah cara memberi supervisi yang konvensional. Ini bukan berarti tidak boleh menunjukkan kesalahan. Masalahnya ialah bagaimana cara kita mengkomunikasikan apa yang dimaksud sehingga para guru menyadari bahwa dia harus memperbaiki kesalahan.

Berdasarkan dari hasil paparan data yang sudah disampaikan, penerapan supervisi konvensional di MA AL-Hikmah Langkapan Srengat cukup membantu dalam upaya meningkatkan kompetensi guru. Karena lewat kegiatan supervisi ini guru akan mengetahui kekurangan atau kelemahan yang perlu diperbaiki sehingga guru dapat mengajar dengan profesional. Meskipun dalam penerapannya supervisi konvensional ini terkesan mematamatai dan mencari kesalahan, namun hal ini tergantung dengan bagaimana cara kepala sekolah mengkomunikasikan hasil dari supervisi sehingga para guru menyadari bahwa dia harus memperbaiki kesalahannya.

\section{Evaluasi Kinerja}

Evaluasi kinerja merupakan salah satu fungsi mendasar personalia, kadang-kadang disebut juga dengan review kinerja, penilaian karyawan atau rating personalia. Dengan kata lain, evaluasi kinerja adalah proses penentuan seberapa baik karyawan melaksanakan tugas mereka. Selain itu, Evaluasi juga dapat diartikan sebagai alat untuk mengukur segala dimensi proses pembelajaran yang telah dilakukan oleh guru. Bagi guru, evaluasi berfungsi untuk mengetahui tingkat ketercapaian dan pemahaman peserta didik terhadap materi yang telah disampaikan, sedang bagi kepala sekolah evaluasi berfungsi untuk mengetahui ketercapaian kurikulum yang telah dilaksanakan oleh guru (Kunandar, 2007:367).

Pada umunya, evaluasi yang dilaksanakan oleh guru lebih banyak berbentuk manual, terutama pada sekolah yang berada di daerah. Walau demikian, tidak dapat dipungkiri bahwa di perkotaan juga masih ada sekolah yang menggunakan sistem evaluasi berbasis manual. Hal ini tergantung kondisi sekolah dan komitmen dari penyelenggara sekolah dalam mengembangkan sistem evaluasinya.

Sementara itu, diadakannya evaluasi kerja sangat membantu dalam upaya meningkatkan kompetensi yang dimiliki guru, hal ini dikarenakan evaluasi kinerja memiliki beberapa manfaat, diantaranya ialah untuk meningkatkan pelaksanaan kerja individu dan unit kerja, komunikasi yang lebih baik, hubungan yang lebih efektif, identifikasi kekuatan-kekuatan dan kelemahan, penemuan masalah yang ada dan potensial, identifikasi kebutuhan akan pelatihan dan pengembangan, penjernihan kerja, peran, dan meningkatkan kesempatan untuk mengungkapkan pandangan (Uno \& Lamatenggo, 2012). Oleh karena itu, evaluasi kinerja sangat penting untuk dilakukan dalam upaya meningkatkan kinerja dan kompetensi guru.

\section{IHT (In House Training)}

IHT atau In House Training diselenggarakan oleh sekolah untuk mempersiapkan guru dalam kegiatan belajar mengajar serta sebagai pewujudan dari upaya peningkatan kompetensi pedagogig yang telah dimiliki oleh guru, pembinaan ini dapat dilakukan oleh pengawas pendidikan, atau kepala sekolah sendiri. Sebagaimana dikatakan Hamdani Bakran Adz-Zakiey, bahwa In House Training merupakan kegiatan pembinaan internal yang dilakukan oleh Kepala 
Sekolah beserta Wakil Kepala Sekolah Bidang Kurikulum dalam rangka meningkatkan kompetensi guru di sekolah (Adz-Zakiey, 2009:341)

Materi pembinaan dalam program IHT diantaranya tentang pendalaman materi mata pelajaran sesuai dengan rumpun masing-masing bidang studi, pelatihan kurikulum yang mencakup: pembuatan RPP, pembuatan SAP, pembuatan Silabus, dan perangkat mengajar lainnya. Selain itu materi pelatihan komputer dan teknologi informasi sebagai bekal bagi guru dalam peningkatan kualitas mengajarnya. Pembinaan ini berlaku kepada semua guru termasuk Guru Pendidikan Agama Islam.

Pembinaan peningkatan dan pengembangan kompetensi guru melalui in house training merupakan usaha yang efektif dan efisien, karena pembinaannya bersifat internal sehingga tidak memerlukan waktu yang lama, tidak memerlukan dana yang besar karena fasilitatornya lebih diutamakan dari internal sekolah seperti Kepala Sekolah, Wakil Kepala Sekolah, serta guru-guru yang kompeten dengan materi yang disajikan, sehingga dapat memberikan hasil yang maksimal. Usaha lewat in house training ini menjadi agenda tahunan yang dilaksanakan di MA Al-Hikmah Langkapan Srengat. Pelaksanaannya pada akhir semsester atau awal semester sehingga tidak menganggu jadwal proses belajar mengajar.

\section{Pembinaan Melalui Kegiatan Rapat dan Supervisi}

Dalam upaya meningkatkan kompetensi kepribadian guru, kepala sekolah selalu memberikan pembinaan yang berupa pembinaan moral, kedisiplinan, pemberian motivasi dan dorongan melalui kegiatan rapat guru dan supervisi. Kemampuan kepala sekolah memegang peranan penting dalam mencapai tujuan sekolah. Motivasi staf dan guru merupakan kekuatan yang mendorong evektifitas dan efesiensi pencapaian tujuan, karena melalui motivasi guru dan staf akan meningkatkan baik dari prestasi dan kepuasan kerja staf serta kreativitasnya.

Dari penjelasan kepala sekolah sebagai seorang pemimpin, kepala sekolah senantiasa memberi motivasi kesegenap guru yang melaksanakan tugasnya dengan profesional baik dengan cara silaturrahmi melalui rapat yang diadakan setiap sebulan sekali karena dengan adanya motivasi kepala sekolah guru akan lebih semangat dalam menjalankan tugasnya. Hal ini dipertegas dengan pendapat Mulyasa (2006:148) yang mengatakan bahwa keberhasilan suatu organisasi atau lembaga dipengaruhi oleh berbagai faktor, baik faktor dari dalam maupun faktor yang datang dari lingkungan. Dari berbagai faktor tersebut, motivasi merupakan suatu yang cukup dominant dan dapat menggerakan faktofaktor lain kearah efektifitas kerja.

Selain pemberian motivasi, melalui kegiatan rapat dan supervisi kepala sekolah juga memberikan pembinaan terkait moral dan sikap, serta bagaimana cara membangun etos kerja atau budaya yang mengutamakan pelayanan bermutu tinggi prima konstituennya yaitu siswa, orang tua dan sekolah sebagai stake holder. Hal ini sebagaimana dikemukakan oleh Mulyasa bahwa dalam peranan sebagai pendidik, kepala sekolah harus berusaha menanamkan, memajukan, dan meningkatkan sedikitnya empat macam nilai yaitu pembinaan mental, moral, fisik dan artistic bagi guru dan staf di lingkungan kepemimpinannya (Mulyasa, 2006:99-100). Dengan begitu, kegiatan rapat yang diagendakan di sekolah sangat membantu dalam upaya meningkatkan dan mengembankan kompetensi guru.

477 BRILIANT: Jurnal Riset dan Konseptual

Volume 2 Nomor 4, November 2017 


\section{Pembinaan dengan Memberikan Keteladanan}

Menampilkan keteladanan dalam rangka memberikan pembelajaran secara non-formal kepada bawahan menjadi langkah yang tepat dan efektif. Oleh karena itu, Kepala MA Al-Hikmah Langkapan Srengat berupaya memberikan keteladanan melalui perbuatan yang dicontohkan seperti kedisiplinan dalam menghargai waktu menekankan kedisiplinan kepada bawahannya dengan memberikan teladan melalui pribadinya yang disiplin dalam segala hal, seperti disiplin dalam waktu, disiplin dalam administrasi, disiplin dalam menyelesaikan semua program kerja sesuai dengan schedule, dan berbagai kedisiplinan lainnya yang melekat pada diri kepalasekolah.

Selain memberikan keteladanan dalam hal kedisiplinan, kepala sekolah juga memberikan keteladanan dalam kepribadian, sopan santun dan lainnya. Peran kepala sekolah dengan menampilkan sifat keteladanan tersebut secara tidak langsung telah membentuk keteladanan dan meningkatkan kedisiplinan Guru Pendidikan Agama Islam secara khusus baik di kalangan peserta didik, sesama teman sejawat, bahkan di lingkungan masyarakat sekitarnya. Keteladanan yang baik mutlak ditampilkan oleh seorang Guru Pendidikan Agama Islam, hal ini sejalan dengan pendapat Adz-Zakiey (2008:341) bahwa guru adalah model dan sumber teladan, oleh karena itu dalam menyampaikan pembelajaran hendaknya sopan, berpenampilan bersih, rapi dan wangi.

Dalam hal disiplin, dapat dilihat dari kedisiplinan guru mengadministrasikan semua dokumen yang terkait dengan kepentingan profesinya. Hal ini juga menunjukkan kedisiplinan yang tinggi yang dimilki oleh Guru Pendidikan Agama Islam. Sementara itu, dalam hal keteladanan, Guru Pendidikan Agama Islam merupakan panutan dan sangat dihormati oleh peserta didiknya serta dihargai oleh teman sejawatnya.

\section{Pertemuan Wali Murid sebagai Upaya Meningkatkan Kemampuan Berkomunikasi Guru dengan Orang Tua Siswa}

Pertemuan dengan wali murid atau orang tua siswa merupkan salah satu bentuk dari hubungan masyarakat (public relation), yang dilakukan sekolah sebagai salah satu upaya dalam meningkatkan kompetensi sosial guru bidang komunikasi. Lewat hubungan masyarakat yang berupa kegiatan pertemuan dengan wali murid dapat dijadikan sebagai salah satu wadah untuk guru belajar mengembangkan ketrampilan komunikasinya. sehingga guru dapat belajar bagaimana berkomunikasi yang baik dan beretika.

Sehubungan dengan kegiatan tersebut, kepala sekolah selalu memberikan kesempatan kepada guru untuk berkomunikasi dengan wali murid lewat kegiatan Misalnya pertemuan rutin sekolah dengan orang tua setiap tahun atau sosialisasi hal-hal penting menyangkut program sekolah, perkembangan belajar siswa, dan lain-lain.

Perlu diketahui, dalam berkomunikasi faktor etika yang terdapat pada diri seorang komunikator yaitu guru sangat penting sekali untuk dimiliki. Bagaiana mungkin seorang komunikator bisa menerobos jiwa seseorang sampai kelubuk hatinya, manakala dia ingkar dari etika. 
Berdasarkan uraian di atas, dapat dikemukakan bahwa pembinaan kompetensi sosial guru melalui pertemuan wali murid sangat membantu dalam upaya meningkatkan kemampuan guru sebagai makhluk sosial dalam berinteraksi dengan orang lain. Sebagai makhluk sosial guru berperilaku santun, mampu berkomunikasi dan berinteraksi dengan lingkungan secara efektif dan menarik

\section{Rapat Guru sebagai Upaya Meningkatkan Kemampuan Berkomunikasi dengan Teman Sejawat}

Membangun hubungan kesejawatan yang baik dan luas termasuk melalui kegiatan rapat guru dan organisasi profesi merupakan salah satu bentuk upaya yang sangat membantu dalam meningkatkan kompetensi guru dalam bidang komunikasi. Karena lewat kegiatan tersebut guru akan belajar bagaimana berkomunikasi yang baik dengan teman sejawatnya. Selain itu, melalui kegiatan ini guru dapat membangun jaringan kerja atau networking, sehingga guru dapat memperoleh akses terhadap innovasi-innovasi di bidang profesinya. Guru harus berusaha mengetahui kesuksesan yang diperoleh oleh teman sejawatnya sehingga ia dapat belajar untuk mencapai sukses yang sama dan bahkan bisa lebih baik lagi.

Perlu diketahui, sesungguhnya komunikasi itu pada dasarnya adalah bagaimana kita meraih perhatian, cinta kasih, minat, kepedulian, simpati, tanggapan maupun responsif dari orang lain (Huda, 2013:81). Dalam membangun komunikasi yang efekti, kita perlu memperhatikan dan menerapkan lima hokum kominikasi yang efekti (The 5 Inevitable Laws of Effective Communication), yang disingkat REACH yang berarti merengkuh atau meraih.

\section{Pembinaan dari Kepala Sekolah Melalui Kegiatan Supervisi}

Pembinaan dari kepala sekolah melalui kegiatan supervisi sebagai upaya meningkatkan kompetensi sosial guru, sebenarnya sama dengan supervisi yang diberikan kepada guru dalam upaya meningkatkan kompetensi pedagogig. Baik dari langkah-lahkahnya ataupun cara penyampaiannya. Yang membedakan aspek kompetensi yang akan disupervisi. Karena misi utama dari supervisi pendidikan itu sendiri adalah memberikan pelayanan kepada guru untuk mengembangkan mutu pembelajaran, memfasilitasi guru agar dapat mengajar dengan efektif. Melakukan kerjasama dengan guru atau setaf lainnya untuk meningkatkan pertumbuhan profesionalisme semua anggota (Suhardan, 2010:37).

Sebagai seorang supervisor, kepala sekolah berfungsi untuk membimbing, membantu dan mengarahkan tenaga pendidik untuk menghargai dan melaksanakan prosedur pendidikan guna menunjang kemajuan pendidikan. Kepala sekolah juga harus mampu melakukan pengawasan dan juga bimbingan untuk meningkatkan kemampuan guru dalam hal bekerja sama dengan teman sejawatnya juga masyarakat.

Oleh karena itu adanya supervisi sangat membantu dalam upaya meningkatkan kompetensi sosial guru. Hal-hal yang perlu diperatikan dan dikembangkan pada diri setiap guru oleh kepala sekolah sebagai supervisor adalah: 1. Kepribadian guru, 2. Peningkatan profesi secara kontinu, 3. Proses pembelajaran, 4. Penguasaan materi pembelajaran, 5. Keragaman kemampuan guru, 6. Keragaman daerah, 7. Kemampuan guru dalam bekerja sama dengan masyarakat (Sahertian, 2000:52).

479 BRILIANT: Jurnal Riset dan Konseptual Volume 2 Nomor 4, November 2017 


\section{KESIMPULAN}

Upaya Sekolah dalam Meningkatkan Kompetensi Pedagogig Guru PAI yang Belum Tersertifikasi Di MA Al-Hikmah Langkapan Srengat diantaranya adalah melakukan workshop, seminar, diklat, MGMP, Supervisi Konvensional, evaluasi kinerja, In House Training. Upaya Sekolah dalam Meningkatkan Kompetensi Kepribadian Guru PAI yang Belum Tersertifikasi Di MA Al-Hikmah Langkapan Srengat diantaranya adalah Pembinaan Melalui Kegiatan Rapat dan Supervisi, Pembinaan dengan Memberikan Keteladanan. Upaya Sekolah dalam Meningkatkan Kompetensi Sosial Guru PAI yang Belum Tersertifikasi Di MA Al-Hikmah Langkapan Srengat diantaranya adalah Pertemuan Wali Murid sebagai Upaya Meningkatkan Kemampuan Berkomunikasi Guru dengan Orang Tua Siswa, Rapat Guru sebagai Upaya Meningkatkan Kemampuan Berkomunikasi dengan Teman Sejawat, Pembinaan dari Kepala Sekolah Melalui Kegiatan Supervisi. Upaya Sekolah dalam Meningkatkan Kompetensi Profesional Guru PAI yang Belum Tersertifikasi Di MA Al-Hikmah Langkapan Srengat diantaranya adalah Supervisi, Diklat, MGMP, Workshop..

\section{SARAN}

Bagi Kepala MA AL-Hikmah Langkapan Srengat, diharapkan lebih inofatif dalam berupaya meningkatkan kompetensi guru, selain mengirimkan guru untuk mengikuti workshop atau diklat undangan hendaknya kepala sekolah juga memprogramkan untuk mengadakan workshop atau diklat secara mandiri di sekolah. Bagi Guru MA AL-Hikmah Langkapan Srengat, semoga dapat lebih kreatif dan inovatif dalam meningkatkan kompetensinya. Beberapa cara yang dapat dilakukan adalah mengikuti kursus kependidikan, melakukan diskusi panel, dan mengembangkan kompetensi dengan banyak membaca buku-buku pengetahuan. Kepada peneliti berikutnya, diharapkan mampu meneliti kembali dan mengungkap fenomena lain yang lebih akurat dan mendalam pada masa-masa yang akan datang.

\section{DAFTAR RUJUKAN}

Adz-Zakiey, HB. 2008. Psikologi Kenabian: Prophetic Psychology. Yogyakarta: Al-Manar.

Arikunto, P. 2002. Prosedur Penelitian Suatu Pendekatan Praktek: Edisi Revisi V. Jakarrta Rineka Cipta.

Basri, H. 2012. Kapita Selekta Pendidikan. Bandung : CV Pustaka Setia.

Danim, S. 2013. Profesionalisasi dan Etika Profesi guru. Bandung.

Hastuti, ADP. 2008. Profesionalisme Guru Dalam Pembelajaran Al-Quran Hadits di MAN Sabdodadi Bantul. Yogyakarta : UIN Sunan Kalijaga.

Huda, MN. 2013. Komunikasi Pendidikan: Teori dan Aplikasi dalam Pembelajaran. Tulungagung : STAIN Tulungagung Press.

Kunandar. 2009. Guru Profesional : Implementasi Kurikulum Tingkat Satuan Pendidikan (KTSP) dan Sukses dalam Sertifikasi Guru. Jakarta: Rajagrafindo Persada.

Lestari, DT. 2017. MGMP Sebagai Upaya Meningkatkan Keprofesionalan Guru IPA SMP Kota Pekanbaru dalam http://lpmpriau.go.id/?p=213, diakses 15 Januari 2017 
Miles, M.B., Huberman, A.M., \& Saldana, J. 2014. Qualitative Data Analysis: A Methods Sourcebook. Third Edition. SAGE Publication Asia-Pacific Pte. Ltd. Singapore.

Mufidah, LLN. 2009. Supervisi pendidikan. Yogyakarta: Teras.

Mulyasa, E. 2008. Standart Kompetensi dan Sertifikasi Guru. Bandung: PT Remaja Rosdakarya.

Musbakin, Imam. 2013. Menjadi Kepala Sekolah yang Hebat. Pekanbaru: Zanafa Publishing.

Purwanto, MN. 1984. Administrasi Pendidikan. Jakarta: Mutiara.

Ramayulis. 2004. Ilmu Pendidikan Islam. Jakarta: Kalam Mulia.

Sahertian, P. 2000. Konsep dasar dan teknik Supervisi Pendidikan Dalam rangka pengembangan sumber daya manusia. Jakarta: Rineka Cipta 2000.

Salim \& Kurniawan. 2012. Studi Ilmu Pendidikan Islam. Jogjakarta: Ar-ruzz Media.

Uno, HB. \& Lamatenggo, N. 2012. Teori Kinerja dan Pengukurannya. Jakarta: PT. Bumi Aksara.

Wahyosumidjo. 2007. Kepemimpinan Kepala Sekolah Tinjauan Teoritik dan Permasalahannya. Jakarta : Rajagrafindo Persada.

Zuriah, N. 2009. Metodologi Penelitian Sosial dan Pendidikan: Teori-Aplikasi. Jakarta: PT. Bumi Aksara. 